\title{
The IJPH turns 100 years old: let's look back!
}

\author{
Brigitte Ruckstuhl ${ }^{1}$
}

Received: 17 March 2020/Revised: 4 May 2020 / Accepted: 7 May 2020/Published online: 20 May 2020

(C) Swiss School of Public Health (SSPH+) 2020

The first issue of the Swiss Journal of Public Health, the oldest "ancestor" of the IJPH, was published in January 1921, and its centennial, eventful history is closely linked to the history of public health in Switzerland (Ruckstuhl and Ryter 2017, Fig. 1). The Journal was initiated by the Swiss Society for Public Health, which was founded on June 12, 1920, as the first professional association in the field of public health in Switzerland. Its predecessor was the Swiss Society for School Health Care, which published yearbooks from 1900 onward. The aim of the new Journal was to strengthen the as yet little organized and barely established discipline of hygiene in Switzerland, to promote exchange between the players in the healthcare system and to link science and practice. The core program of the Society included the organization of annual scientific conferences and the publication of the Journal.

The first editor, Willi von Gonzenbach, head of the Institute for Hygiene and Bacteriology at the Swiss Federal Institute of Technology (ETH) in Zurich, was solely responsible for the Journal for 34 years. He was a representative of social hygiene and was interested in the connections between social, cultural and biological aspects of health and disease. In the first issue of the Journal, he pointed out that the most common diseases such as tuberculosis, venereal diseases and alcoholism are primarily rooted in social conditions and that the Journal should therefore focus on social hygiene. The Journal aimed at communicating and disseminating practical experiences

Brigitte Ruckstuhl, PhD, MPH, works as a historian in the field of Public Health. She has researched and published (in German) on the history of Public Health in Switzerland.

This editorial is published to mark the 100th anniversary of the International Journal of Public Health.

\section{Brigitte Ruckstuhl}

brigitte_ruckstuhl@bluewin.ch

https://www.brigitte-ruckstuhl.ch/

1 Bern, Switzerland and research results. In addition to conference papers, the Journal published articles on a wide range of topics-from medical, social to architectural issues. Even though the Journal faced financial problems and changed its name several times, the long-time committed editor and the consistent sponsorship by the Swiss Society for Public Health ensured constancy of content.

The death of Willi von Gonzenbach in the mid-1950s marked change in both the Society and the Journal. From 1956, the Swiss Society for Health Care called itself the Swiss Society for Preventive Medicine and the Journal was renamed Journal for Preventive Medicine (Zeitschrift für Präventivmedizin). The social background for these changes was the changing field of tasks in the public health system, caused by a shift in the spectrum of diseases toward chronic diseases. As a result, the field preventive medicine emerged, which focused on research into risk factors for chronic diseases and their prevention. In Switzerland, there was a need for action in this area. Research facilities for this task were lacking, as the existing hygiene institutes were now limited to microbiological research. The Society for Preventive Medicine pointed out the deficit with its new name. University Institutes for Social and Preventive Medicine were founded between 1962 and 1972 to fill the gap. These institutes focused on risk factor medicine as a discipline and thus shaped the Journal's content. From 1972 onward, the editorial staff moved from the ETH to the Institute of Social and Preventive Medicine in Zurich. When the development of New Public Health in the 1980s led to reforms of the healthcare system, the Journal again assumed an important function in dealing with necessary transformations. The editors focused on the professionalization of the public health workforce and structural changes in the healthcare system, to strengthen the public health system and especially health promotion and prevention (Schweizerische Gesellschaft für Sozial- und Präventivmedizin 1986). For decades, the Journal promoted exchange between public health players and supported discussions on health and professional policy issues in Switzerland. A further transformation, which again led to a change of the Journal's 


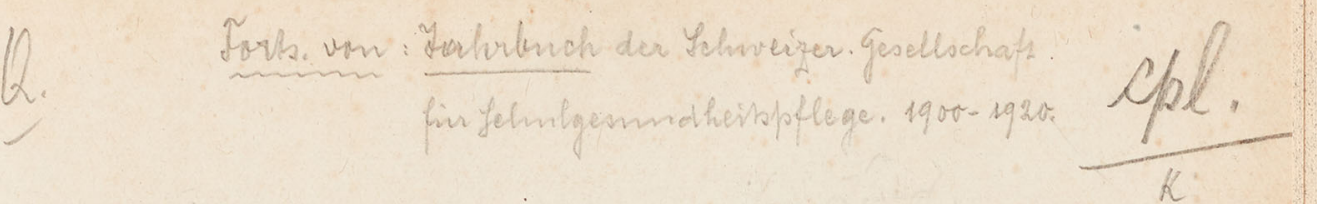 \\ Schweizerische Zeitschrilft \\ fiir Gesundheitspilege \\ Revue suisse d'hygiène \\ Rivista svizzera d'igiene}

Fortsetzung des Jahrbuches der

Schweizerischen Gesellschaft

für Schulgesundheitspflege

Suite des annales de la Société

suisse d'hygiène scolaire

Herausgegeben von der Schweizerischen Gesellschaft für

Gesundheitspflege

Publiée par la Société suisse d'hygiène

Redaktion: Dr. med. W. v. GonzENBACH

Professor der Hygiene an der Eidg. Techn. Hochschule

I. Jahrgang 1921 Ire Année

Io Anno

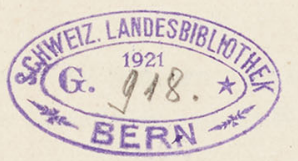

Zürich

Druck und Verlag Buchdruckerei Gebr. Fretz A. G.

Fig. 1 Cover of the first issue of the Swiss Journal of Public Health, published by the Swiss Society of Public Health in January 1921 
name, became apparent in the 1990s. The Swiss Society for Prevention and Health Care became Public Health Switzerland. This was associated with a stronger international orientation, particularly toward the WHO's Health for All program up to the year 2000 (Schweizerische Gesellschaft für Sozial- und Präventivmedizin 1997). The Journal already had anticipated the international orientation by publishing articles in English, German and French (Ackermann-Liebrich and Marti 1992). When the editorial staff moved from Zurich to the Institute for Social and Preventive Medicine at the University of Bern in 2001, the editors explicitly formulated the new orientation (Abel and Morabia 2001): The aim was a more stringent focus on content, broader support through partnerships and cooperation, and a stronger international orientation. The newly introduced subtitle International Journal of Public Health made this orientation visible. The shift to an international Journal was completed in 2007 (Abel 2007). Since then, the sole title of the Journal is International Journal of Public Health, and all contents are published in English only and the Journal received an Impact Factor. With these changes, the importance of the Journal as a platform and voice for public health professionals in Switzerland has declined, but it opened up new perspectives and enabled a clearer scientific profile. The new course ensured sustainable finances and the development into a leading scientific public health Journal. Since 2010, the Swiss School of Public Health $(\mathrm{SSPH}+)$ is the owner of IJPH and a fruitful new partnership began.

\section{Compliance with ethical standards}

Conflict of interest The author declares that she has no conflict of interest.

\section{References}

Abel T (2007) New name and new perspectives for the International Journal of Public Health, formerly SPM. Int J Public Health 52:1. https://doi.org/10.1007/s00038-006-6104-4

Abel T, Morabia A (2001) New structures and new perspectives for Social and Preventive Medicine: the International Journal of Public Health. Sozial- und Präventivmedizin 46:1

Ackermann-Liebrich U, Marti B (1992) Editorial choices: to expand or not to expand.... Sozial- und Präventivmedizin 37:149-150

Ruckstuhl B, Ryter E (2017) Von der Seuchenpolizei zu Public Health. Öffentliche Gesundheit in der Schweiz seit 1750. Chronos, Zürich

Schweizerische Gesellschaft für Sozial- und Präventivmedizin (ed) (1986) Gesundheitsförderung und Prävention in der Schweiz. Leitbild 86. Offprint of the Journal

Schweizerische Gesellschaft für Sozial- und Präventivmedizin (ed) (1997) Gesundheit für alle. Ziele zur Gesundheitspolitik für die Schweiz. Sozial- und Präventivmedizin 42(Suppl1):80

Publisher's Note Springer Nature remains neutral with regard to jurisdictional claims in published maps and institutional affiliations. 